\title{
An Uncommon Cause of Duane Syndrome in a Child: Wildervanck Syndrome
}

\section{Duane Sendromunun Nadir Bir Nedeni: Wildervanck Sendromu}

\author{
Ahmet Anık1, Şiar Dursun2, Ahmet Polat3, Ayşe Anık4, Tolga Ünüvar1, Yasemin Durum5, \\ Ayşe Fahriye Tosun2 \\ ${ }^{1}$ Adnan Menderes University Faculty of Medicine, Department of Pediatric Endocrinology, Aydın, Turkey \\ ${ }^{2}$ Adnan Menderes University Faculty of Medicine, Department of Pediatric Neurology, Aydın, Turkey \\ ${ }^{3}$ Adnan Menderes University Faculty of Medicine, Department of Family Medicine, Aydın, Turkey \\ ${ }_{4}^{4}$ Adnan Menderes University Faculty of Medicine, Department of Pediatrics, Aydın, Turkey \\ 5 Adnan Menderes University Faculty of Medicine, Department of Radiology, Aydın, Turkey
}

\begin{abstract}
Duane syndrome is a congenital eye movement disorder characterized by limitation of abduction and/or adduction accompanied with lid fissure narrowing, and globe retraction in attempted adduction. Duane syndrome is mostly an isolated entity, but systemic anomalies have been reported in $6-10 \%$ of patients. Wildervanck syndrome (cervico-oculo-acoustic syndrome) is a very rare disease comprised of the triad of Klippel-Feil deformity (congenitally fused cervical vertebrae), Duane syndrome, and hearing loss. The disorder is limited, or almost completely limited, to females, raising the question of sex-linked dominance with lethality in the hemizygous male. Herein, we describe an adolescent girl who was admitted to our clinic for obesity and diagnosed with Wildervanck syndrome due to bilateral abducens paralysis (Duane syndrome), Klippel-Feil deformity and hearing loss.

Keywords: Duane syndrome, klippel-feil anomaly, hearing loss, wildervanck syndrome
\end{abstract}

\section{Introduction}

Duane syndrome is a congenital eye movement disorder characterized by a limitation of abduction and/or adduction of the affected eye, with associated narrowing of the space between the eyelids on adduction and globe retraction (1).
ÖZ

Duane sendromu etkilenen gözde abdüksiyon ve/veya addüksiyonun kısıtlanması ile beraber adduksiyonda göz kapağı aralığının daralması ve glob retraksiyonu ile karakterize bir doğumsal göz hareketi bozukluğudur. Olguların çoğunda Duane sendromu izole bir bulgu iken hastaların \%6-10'unda diğer organ anomalileri de gözlenebilmektedir. Wildervanck sendromu (servikookülo-akustik sendrom), Duane sendromu ile birlikte fasiyal asimetri, kulak anomalileri, işitme kaybı ve Klippel-Feil deformitesi gözlenmesidir ve oldukça nadir görülmektedir. Olguların tamamına yakınının kız olması nedeniyle, Wildervanck sendromunun hemizigot erkeklerde ölümcül olan, cinsiyete bağlı kalıtılıı̆ı düşünülmektedir. Bu olgu sunumunda obezite nedeni ile başvuran ve bilateral abducens paralizisi (Duane sendromu), Klippel-Feil anomalisi ve işitme kaybı saptanarak Wildervanck sendromu tanısı konan adölesan bir kız olgu sunulmuştur.

Anahtar Kelimeler: Duane sendromu, klippel-feil anomalisi, işitme kaybı, wildervanck sendromu

Duane syndrome is familial in approximately $10 \%$ of the patients, and it may be associated with some syndromes such as Wildervanck syndrome (cervico-oculo-acoustic syndrome) (OMIM 314600) (1). Wildervanck syndrome is a developmental defect of the cerebellum and brainstem and a segmental anomaly of vertebrae, which is characterized by the 
co-existence of congenital hearing loss, Klippel-Feil anomaly (congenital cervical vertebral fusion), and Duane syndrome (2). This syndrome was first defined by Wildervanck in 1952 and is suggested to result from the defects in the axon guidance and neuronal migration in the developing nervous system $(2,3)$. Wildervanck syndrome was also reported to be associated with some malformations of the central nervous system $(4,5)$. It is believed to have sex-linked inheritance with lethality to hemizygous males since it is much more common in females; however, polygenic inheritance was reported to be more likely (6).

\section{Case Report}

A fifteen-year old girl presented with weight gain. It was ascertained from her history that she was born of a full term delivery, weighing $3.800 \mathrm{~g}$ following a problem-free pregnancy, and she was under follow-up due to the diagnosis of congenital anomaly and conductive hearing loss of in the right ear. The parents were not consanguineous and there were no other family members with similar complaints. It was found on physical examination that she weighed 78.2 $\mathrm{kg}(90-97 \mathrm{p})$ and she was $156 \mathrm{~cm}$ tall (10-25 p). Her body mass index was $32.1 \mathrm{~kg} / \mathrm{m} 2$ (>95 p, +2 SDS) and she had facial asymmetry, atresia of the right external auditory canalanomaly of the right auricle and preauricular skin tag, a short and webbed neck, and limitations in neck movements. Neurological examination revealed a limitation of outward movement in both eyes and narrowing of the palpebral fissure on inward movement in both eyes (Figure 1).

Whole blood count, serum aspartate transaminase, alanine transaminase, urea, creatinine, lipid profile, and thyroid hormones were normal. Impaired fasting glucose was found from the standard oral glucose tolerance test. Anterior eye segment and retina were normal but the neck radiography showed Klippel-Feil anomaly (C1-C2 and C4-C5 vertebral fusion), and the computed tomography of temporal bone revealed atresic right external auditory canal, hyperplasic mastoid bone and deformed ossicles. The audiological assessment showed that hearing of in the left ear was normal. As a result of cranial magnetic resonance imaging, it was seen that the cerebellar tonsils had migrated $11 \mathrm{~mm}$ caudal to the foramen magnum (Figure 2).

Impaired fasting glucose was associated with exogenous obesity, and the patient was discharged under treatment with metformin $2.000 \mathrm{mg} /$ day.

\section{Discussion}

The genetic transition of the Wildervanck syndrome is not exactly known; however, it is believed to have x-linked inheritance with lethality to hemizygous males since it is common in females. Recently, an Xq26.3 microdeletion was reported in a male with Wildervanck syndrome and it was reported that the $\mathrm{X}$-chromosome deletions might cause Wildervanck syndrome and greater deletions might be lethal to males. Additionally, the same study reported that the FGF13 mutation might cause Wildervanck syndrome (7). The present case had typical features of Wildervanck syndrome and was also female, which was considered consistent with the literature findings.

Duane syndrome is bilateral in approximately $17 \%$ of the cases and it was bilateral in the present case, too (8).

The hearing loss may be sensorineural, conductive, or mixed in Wildervanck syndrome, and these patients may have malformations of external auditory canal, external acoustic meatus, ossicles and bony labyrinth $(9,10)$. The present case also had atresia of right external auditory canal and anomalies of mastoid bone and ossicles, whereas the hearing in the right ear was normal.

Klippel-Feil anomaly is a bone anomaly defined by the fusion of two or more cervical vertebrae, with an incidence of $1 / 42.000$. It is clinically characterized by short neck, limited neck movements, and a low hairline (11). The neck radiography, which was performed due to the short neck and limited neck movements, showed that the present case also had cervical vertebral fusion.

These patients are rarely reported to have cerebellar hypoplasia, lower brainstem malformations, and/or triventricular hydrocephalus and even more rarely to have several associated anomalies such as congenital heart diseases, agenesis of the internal carotid artery, short stature,
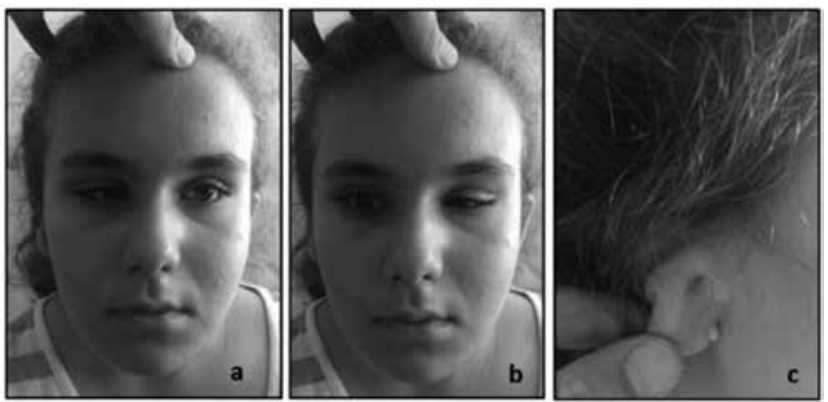

Figure 1. a) Facial asymmetry, limitation of outward movement of the left eye and ptosis of the right eye, b) Limitation of outward movement of the right eye, and ptosis of the left eye, c) Anomaly of right auricle, atresia of right external auditory canal, and preauricular skin tag

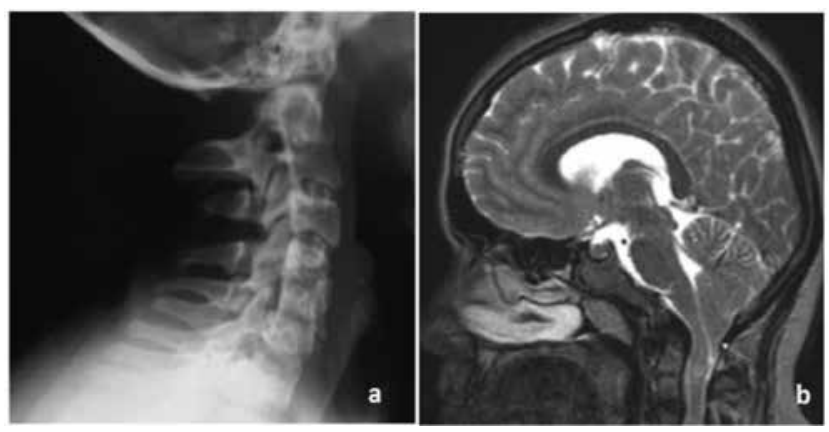

Figure 2. a) Klippel-Feil anomaly characterized by $\mathrm{C} 1-\mathrm{C} 2$ and $\mathrm{C} 4-$ C5 fusion, b) T2-weighted sagittal section of cranial MRI shows cerebellar tonsils herniation 
microcephaly, mental retardation, cleft palate, and hypoplastic frontal sinus $(4,12-14)$. The cranial MRI of the present case showed that the cerebellar tonsils had migrated $11 \mathrm{~mm}$ caudal to the foramen magnum.

The present case report has aimed to highlight the fact that Duane syndrome should be considered in patients with congenital bilateral abducens paralysis, and patients should be investigated for associated pathologies.

\section{Ethics}

Informed Consent: Patient consent was obtained.

Peer-review: Externally peer-reviewed.

\section{Authorship Contributions}

Surgical and Medical Practices: Ahmet Anık, Ahmet Polat, Yasemin Durum, Tolga Ünüvar, Concept: Ahmet Anık, Ayşe Anık, Design: Ahmet Anık, Ayşe Anık, Data Collection or Processing: Ahmet Anık, Tolga Ünüvar, Analysis or Interpretation: Ahmet Anık, Ayşe Fahriye Tosun, Literature Search: Şiar Dursun, Ayşe Anık, Writing: Ahmet Anık.

Conflict of Interest: No conflict of interest was declared by the authors.

Financial Disclosure: The authors declared that this study received no financial support.

\section{References}

1. DeRespinis PA, Caputo AR, Wagner RS, Guo S. Duane's retraction syndrome. Surv Ophthalmol 1993;38:257-88.

2. Wildervanck LS. [A case of Klippel-Feil's syndrome with abducens paralysis; retraction of the eyeball and deafmutism]. Ned Tijdschr Geneeskd 1952;96:2752-6.
3. Engle EC. Human genetic disorders of axon guidance. Cold Spring Harb Perspect Biol 2010;2:001784.

4. Balci S, Oguz KK, Firat MM, Boduroglu K. Cervical diastematomyelia in cervico-oculo-acoustic (Wildervanck) syndrome: MRI findings. Clin Dysmorphol 2002;11:125-8.

5. Dirik E, Yiş U, Dirik MA, Cakmakçi H, Men S. Vertebral artery dissection in a patient with Wildervanck syndrome. Pediatr Neurol 2008;39:218-20.

6. Wettke-Schafer R, Kantner G. X-linked dominant inherited diseases with lethality in hemizygous males. Human Genet 1983;64:1-23.

7. Abu-Amero KK, Kondkar AA, Alorainy IA, et al. Xq26.3 microdeletion in a male with Wildervanck Syndrome. Ophthalmic Genet 2014;35:18-24.

8. Zanin E, Gambarelli N, Denis D. Distinctive clinical features of bilateral Duane retraction syndrome. J AAPOS 2010;14:2937.

9. Danilidis J, Demetriadis A, Triaridis C, Manolidis L. Otological findings in cervico-oculo-auditory dysplasia. J Laryngol Otol 1980;94:533-44.

10. Cremers CW, Hoogland GA, Kuypers W. Hearing loss in the cervico-oculo-acoustic (Wildervanck) syndrome. Arch Otolaryngol 1984;110:54-7.

11. Klimo P Jr, Rao G, Brockmeyer D. Congenital anomalies of the cervical spine. Neurosurg Clin N Am 2007;18:463-78.

12. Meshram SS, Nikose S, Jain S, Taksande A. Wildervanck syndrome with hypoplastic frontal sinus: A rare case presentation. Indian J Hum Genet 2014;20:189-91.

13. Hernando M, Urbasos M, Amarillo VE, et al. Wildervanck's syndrome with severe inner ear dysplasia and agenesis of the right internal carotid artery. Int J Pediatr Otorhinolaryngology 2014;78:704-6

14. Kumar A, Chaudhary D, Gupta SK. Wildervanck syndrome. Australasian Radiol 1996;40:160-1. 